\title{
DESAIN SISTEM KONTROL TRAFFIC LIGHT ADAPTIF PADA PERSIMPANGAN EMPAT BERBASIS PLC SIEMENS
}

\author{
Zulfikar, Tarmizi, Oktavina \\ Jurusan Teknik Elektro, Universitas Syiah Kuala, Banda Aceh, Indonesia \\ e-mail: zulfikarsafrina@yahoo.co.id
}

\begin{abstract}
Abstrak-Traffic light yang ada saat ini masih menggunakan waktu tetap sebagai pengendali nyala lampunya. Namun sistem ini memiliki kekurangan, salah satunya pada jam sibuk kendaraan harus menunggu lama disalah satu jalur. Sehingga diperlukan suatu sistem kontrol traffic light yang dapat memprioritaskan jalur yang lebih padat kendaraan. Kontrol traffic light adaptif bekerja dengan mendeteksi jumlah antrian kendaraan pada suatu jalur. Sistem ini bekerja dengan sensor yang mendeteksi panjang antrian kendaraan. Terdapat tiga sensor yang akan mendeteksi panjang antrian kendaraan pada setiap jalur. Jika antrian kendaraan mencapai sensor pertama maka waktu yang diberikan pada lampu hijau adalah 5 detik lebih lama dari waktu normal pada jalur tersebut. Jika antrian kendaraan mencapai sensor kedua maka waktu yang diberikan pada lampu hijau adalah 10 detik lebih lama dari waktu normal dan jika antrian kedaraan telah mencapai sensor ketiga sistem akan memberikan waktu nyala lampu hijau sangat lama yaitu 15 detik lebih lama dari waktu normal. Pada sistem kontrol traffic light adaptif ini terdapat dua buah sensor kemacetan yang diletakkan pada pertengahan jalur simpang empat yang akan menghidupkan seluruh lampu merah jika terjadi hal tidak terduga seperti saat setelah padamnya aliran listrik. Dengan sistem kontrol traffic light adaptif ini waktu terlama antrian kendaraan adalah 92 detik, jika seluruh sensor pada setiap jalur bekerja dan waktu tercepat adalah 47 detik yaitu waktu pada saat normal.
\end{abstract}

\section{Kata kunci: Traffic light, PLC Siemens Simatic S-7 300, Sensor Kemacetan, Traffic Light Adaptif.}

\begin{abstract}
Nowadays, traffic lights are using a fixed time as on-off light signal controller. However this system has many disadveantages, such as vehicles have to queue long time in certain road section (lane) at rush hour. As a consequence, it reguires a traffic light control system that can prioritize a more dense lane. Adaptive traffic light control detects the number of queues of vehicles on the lane. Sensors detect the vehicle queue's length. There are three sensors that will detect queues's length of vehicles on each lane. When the queue of vehicles reached the first sensor, the green light will be on longer 5 seconds compare to the normal traffic. When the queue of vehicles reaches the second sensor, the green light provide 10 seconds more compare to the normal traffic and if the queue of vehicles reaches the third sensor, the green light will be longer whic is about 20 seconds compare. In this adaptive traffic light control system, there are two jam sensors installed in the middle of the intersection that will turn on all the red lights when there is an unexpected problems happened. This adaptive traffic light control system will provide the longest queuing time 92 seconds, when all sensors on all lanes active and the fastest time is 47 seconds which is the time when the normal system.
\end{abstract}

Keywords: Traffic light, PLC Siemens S-7 300, Traffic Sensor, Adaptive Traffic Light.

\section{PENDAHULUAN}

Pada umumnya, traffic light menggunakan sistem waktu tetap. Kendaraan pada sebuah jalur dapat berjalan jika waktu yang diberikan telah mencapai batas waktu tunggu yang ditentukan. Sistem tersebut memiliki kekurangan, karena jumlah kendaraan yang melewati suatu jalur menuju persimpangan bervariasi terhadap waktu. Sehingga pada jamjam sibuk kedaraan harus menunggu lama pada satu jalur, sementara jalur lain tidak dan bahkan kadang-kadang ada jalur yang tidak ada kendaraan sama sekali. Untuk mengatasi hal ini diperlukan suatu sistem yang dapat memberikan waktu lebih lama pada suatu jalur menurut tingkat kepadatan kendaraan.

Banyak sistem pengontrolan traffic light fleksibel yang telah dirancang. Salah satunya adalah pengendalian traffic light mengunakan media RF. Sistem komunikasi yang dibuat dengan komputer akan mengirimkan data sebagai perintah yang dilakukan ke mikrokontroler AT89C51 melalui media HT (Handy Talky). Data yang diterima oleh 
mikrokontroler merupakan data untuk mengatur mode pada nyala lampu traffic light [1].

Selain itu, telah ada sistem pengatur lampu lalu lintas yang dikendalikan dari jarak jauh. Sistem ini bekerja menggunakan kamera video untuk memonitor arus lalu lintas melalui gambar bergerak. Gambar tersebut akan dikirim oleh transmitter pada traffic light ke receiver dipusat pengendali melalui Ultra Hight Frequency (UHF). Operator akan mengubah lama nyala lampu pada traffic light sesuai dengan pengamatan yang dilakukan dari kamera video. Mikrokontroler mengeksekusi data dan mengirimkan konfirmasi berupa data yang sama ke komputer [2].

Penelitian pengontrolan traffic light mengunakan PLC yang pernah lakukan adalah dengan sistem sensor yang dipasang pada badan jalan untuk mendeteksi ada tidaknya kendaraan. Sistem ini memiliki beberapa kondisi diantaranya kondisi normal yang memiliki phase dimana lampu merah dan hijau disetiap phase memiliki perbedaan waktu. Pada kondisi otomatis sistem bekerja dalam 4 kondisi yaitu: kondisi kosong, kondisi padat, kondisi prioritas, dan kondisi emergency [3].

Selanjutnya, sistem pengontrolan traffic light secara otomatis [4]. Sistem traffic light otomatis ini berbasis mikrokontroler AT89C51 sebagai pengontrol sistem utamanya. Sistem ini berkerja dengan menggunakan sensor yang dipasang disisi persimpangan jalan. Sensor ini digunakan untuk mendeteksi banyaknya kendaraan yang mengantri pada persimpangan traffic light. Sistem ini juga dilengkapi dengan sensor yang mendeteksi kemacetan yang diakibatkan padamnya listrik.

Sistem tersebut memiliki kelemahan, sinyal kontrol yang di keluarkan oleh mikrokontroler sangat lemah untuk bisa menghidupkan lampu traffic light yang sebenarnya. Oleh karena itu, penulis merancang suatu sistem kontrol traffic light adaptif berbasis PLC. Output dari PLC dapat langsung dihubungkan ke lampu traffic light sebenarnya.

Selanjunya pada bagian 2 akan dijelaskan teori-teori pendukung dalam penulisan penelitian ini. Bagian 3 menjelaskan perancangan sistem traffic light adaptif yang digunakan pada penelitian ini. Hasil dan pembahsan disajikan pada bagian 4. Bagian 5 menampilkan kesimpulan.

\section{DASAR TEORI}

Berikut akan disajikan beberapa teori pendukung dalam penelitian ini, seperti teori tentang traffic light dan PLC Siemens.

\section{A. Traffic Light}

Traffic light adalah sebuah alat pengendali arus lalu lintas menggunakan lampu yang dipasang pada persimpangan jalan. Tujuannya untuk mengatur arus lalu lintas pada setiap persimpangan agar dapat berjalan secara teratur dan tidak saling bertabrakan.[5]

Lampu lalu lintas atau traffic light dikenal pertama kali pada tahun 1868. Sistem menggunakan gas yang dipasang di Westminter Inggris. Kemudian pada tahun 1918 di New York, dengan format merah, kuning, hijau yang dioperasikan secara manual. Pada tahun 1926 dilakukan operasi lampu secara semi otomatis di wolverhampton Inggris. Secara garis besar traffic light digunakan sebagai pengatur arus lalu lintas, mencegah kemacetan di persimpangan, memberikan kesempatan kepada kendaraan lain/ pejalan kaki dan meminimalisasi konflik kendaraan [5].

Saat ini pegaturan lampu lalu lintas yang digunakan masih menggunakan sistem standalone. Dimana lama waktu nyala lampu hijau dan merah di atur secara konstan atau waktu tetap. Sehingga sistem ini tidak sesuai dengan kondisi yang terjadi pada lalu lintas yang volume kendaraan bervariasi setiap waktu. Sistem traffic light ini tidak bersifat adaptif [6]. Traffic light bersifat adaptif adalah waktu lamanya kendaraan menunggu dapat berubah sesuai dengan tingkat kepadatan pada masingmasing jalur [7].

\section{B. PLC Siemens Simatic S-7 300}

PLC Siemens memiliki memori seperti internal relay, spesial relay, data memori dan komponen lainnya. Pengalamtan pada PLC Siemens menggunakan bilangan oktal, perhitungan di mulai dari 0 sampai 7. Pada umumnya PLC Siemens untuk alokasi alamat yang berhubungan langsung pada terminal input modul menggunakan awalan huruf I, sedangkan untuk alokasi alamat yang berhubungan langsung pada terminal output modul menggunakan awalan huruf Q. Untuk internal relay/ internal memori menggunkan pengalamatan awalan huruf M [8]. 
Siemens S-7 300 merupakan salah satu jenis PLC buatan yang berbentuk modular. Komponen-komponen sistem S7-300 disusun dari beragam komponen modular. Adapun komponen-komponen tersebut meliputi :

1. Modul power supply (PS)

2. Central processing unit (CPU)

3. Sinyal modul (SM)

4. Function modul (FM)

5. Processor communications (CP)

Pemrograman pada PLC Siemens S7-300 dapat dilakukan dengan 5 cara, sehingga pengguna dapat memilih cara pemrograman yang lebih mudah untuk digunakan. Adapun kelima bahasa pemrograman yang tersedia adalah [8]:

1. Statement List (STL)

2. Ladder Diagram (LAD)

3. Function Block Diagram (FBD)

4. Step 7 (S7)

5. Structured Control Language

\section{PERANCANGAN SISTEM}

\section{A. Blok Diagram Sistem}

Gambar 1 merupakan blok diagram jalannya sistem. Sensor inframerah akan mendeteksi adanya kendaraan disetiap jalur. Output dari sensor kemudian akan dikirimkan ke PLC dan untuk mengolah data yang kemudian diteruskan ke setiap jalur dan mengatur penyalaan LED sebagai penanda lampu lalu.

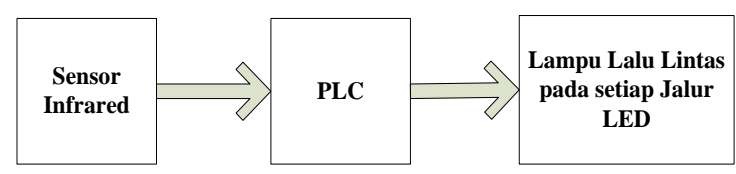

Gambar 1. Blok diagram perancangan sistem

\section{B. Perancangan Sistem Kerja}

Adapun sketsa perancangan sistem yang dirancang dapat dilihat pada Gambar 2. Gambar tersebut memperlihatkan semua sensor yang dipasang pada setiap jalur. Setiap jalur dipasang tiga buah sensor. Sensor-sensor ini akan mendeteksi tingkat kemacetan dari setiap jalur. Sistem juga dilengkapi dengan sensor di tengah-tengah persimpangan untuk mendeteksi kemacetan total di persimpangan.

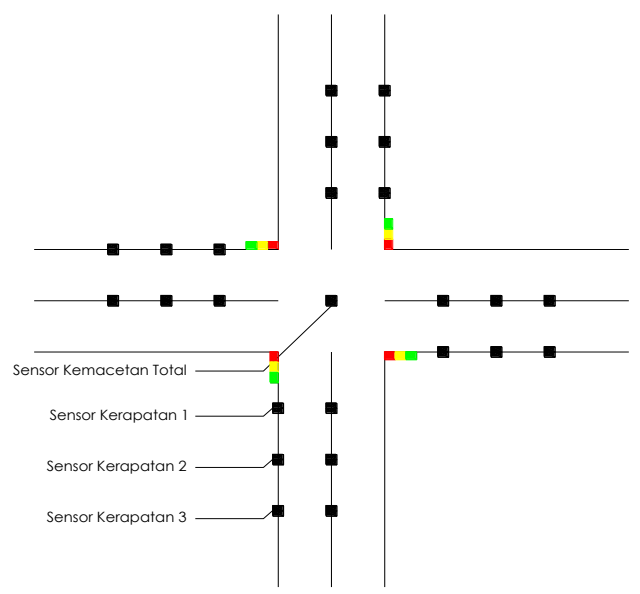

Gambar 2. Sketsa perencanaan Traffic light adaptif

Deskripsi pengaturan traffic light dapat dilihat pada diagram Gambar 3. Pengaturan traffic light dibagi dalam tiga tingkatan, yaitu sistem normal, sistem sensor (sistem kepadatan) pada jalur dan kemacetan total. Jika sistem beroperasi pada keadaan normal, maka tidak ada prioritas terhadap jalur-jalur tertentu. Ketika sistem beroperasi pada mode kemacetan total, semua jalur ditutup. Artinya semua kendaraan tidak diperbolehkan melewati persimpangan.

Sistem kepadatan (sistem sensor) dibagi menjadi tiga sub sistem, yaitu kepadatan tingkat 1, kepadatan tingkat 2 dan kepadatan tingkat 3. Tiga buah sensor yang dipasang pada masingmasing jalur digunakan untuk menentukan tingkat kepadatan kendaraan yang mengantri.

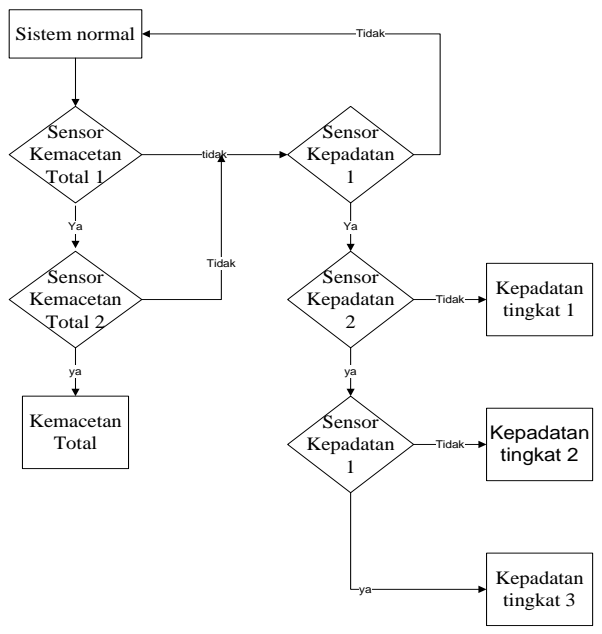

Gambar 3. Diagram alir jalannya pengaturan traffic Light 


\section{Perancangan Perangkat Keras}

Pada sistem ini, PLC Siemens Simatic digunakan sebagai perangkat utama pengendalian lampu lalu lintas. Sistem ini memiliki 14 sensor pengatur kepadatan lalu lintas, yaitu 12 sensor pada keempat jalur dan 2 pada petengahan traffic light serta 12 lampu traffic light.

Tabel 1 dan 2 memperlihatkan hubungan antara input/ output yang dialamatkan pada hardware dan software..

Tabel 1. Pengalamatan input dari sistem

\begin{tabular}{|c|c|c|}
\hline \multicolumn{3}{|c|}{ Input } \\
\hline Hardware & Software & Alamat \\
\hline DI-0.1 & I 124.1 & Memulai program \\
\hline DI-0.2 & I 124.2 & Mematikan program \\
\hline DI-0.3 & I 124.3 & Sensor 1 jalur 1 \\
\hline DI-0.4 & I 124.4 & Sensor 2 jalur 1 \\
\hline DI-0.5 & I 124.5 & sensor 3 jalur 1 \\
\hline DI-1.0 & I 125.0 & Sensor 1 jalur 2 \\
\hline DI-1.1 & I 125.1 & Sensor 2 jalur 2 \\
\hline DI-1.2 & I 125.2 & Sensor 3 jalur 2 \\
\hline DI-1.4 & I 125.4 & Sensor 1 jalur 3 \\
\hline DI-1.5 & I 125.5 & Sensor 2 jalur 3 \\
\hline DI-1.6 & I 125.6 & Sensor 3 jalur 3 \\
\hline DI-2.0 & I 126.0 & Sensor 1 jalur 4 \\
\hline DI-2.1 & I 126.1 & Sensor 2 jalur 4 \\
\hline DI-2.2 & I 126.2 & Sensor 3 jalur 4 \\
\hline DI-0.6 & I 124.6 & $\begin{array}{r}\text { sensor kemacetan total } \\
\text { pada pertengahan } \\
\text { simpang 4 }\end{array}$ \\
\cline { 1 - 1 } DI-0.7 & I 124.7 & \multicolumn{2}{|c}{} \\
\cline { 1 - 2 }
\end{tabular}

Tabel 2. Pengalamatan output dari sistem

\begin{tabular}{|c|c|c|}
\hline \multicolumn{3}{|c|}{ Output } \\
\hline Hardware & Software & Alamat \\
\hline DO-0.0 & Q124.0 & Merah pada jalur 1 \\
\hline DO-0.1 & Q124.1 & Hijau pada jalur 1 \\
\hline DO-0.2 & Q124.2 & Kuning pada jalur 1 \\
\hline DO-0.5 & Q124.5 & Merah pada jalur 2 \\
\hline DO-0.6 & Q124.6 & Hijau pada jalur 2 \\
\hline DO-0.7 & Q124.7 & Kuning pada jalur 2 \\
\hline DO-1.0 & Q125.0 & Merah pada jalur 3 \\
\hline DO-1.1 & Q125.1 & Hijau pada jalur 3 \\
\hline DO-1.2 & Q125.2 & Kuning pada jalur 3 \\
\hline DO-1.5 & Q125.5 & Merah pada jalur 4 \\
\hline DO-1.6 & Q125.6 & Hijau pada jalur 4 \\
\hline DO-1.7 & Q125.7 & Kuning pada jalur 4 \\
\hline
\end{tabular}

Gambar 4 memperlihatkan rangkaian hubungan sensor, lampu LED dengan PLC. Sumber tegangan berasal dari power supply PLC. Khusus pada rangkaian infrared di gunakan IC regulator LM7805 untuk menurunkan tegangan sumber 24 Volt DC menjadi 5 Volt DC.

Sistem bekerja bila antara infrared dan photodioda terhalang kendaraan. C9013 berfungsi sebagai saklar, jika rangkaian infrared bekerja C9013 akan mengirimkan sinyal ke PLC. Jika tidak ada sinyal dari rangkaian infrared, maka PLC akan menjalankan sistem nomal, jika PLC menerima sinyal dari infrared, PLC akan menjalan sistem kepadatan atau kemacetan total. LED berfungsi sebagai indikator Traffic Light. DI (digital input) dan DO (digital output) digunakan sebagai penghubung antara hardware ke software/ program.

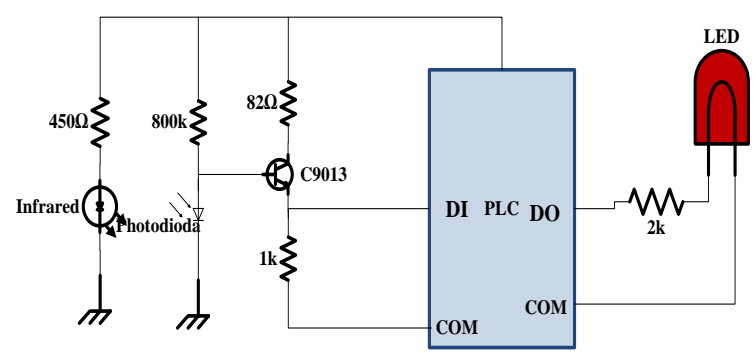

Gambar 4. Rangkaian sistem pada suatu jalur

\section{Perancangan Perangkat Lunak}

Perancangan program pengaturan traffic light sistem normal dimulai dengan lampu merah menyala pada semua jalur beberapa detik. Kemudian, lampu hijau menyala (lampu merah pada jalur tersebut padam) pada salah satu jalur. Setelah lampu hijau mati, maka lampu kuning akan hidup. Akhirnya lampu merah akan hidup kembali, setelah lampu kuning padam. Kemudian sistem akan berulang pada jalur berikutnya.

Pada sistem kepadatan, lampu hijau pada jalur-jalur yang antrian kendaraannya mencapai sensor akan hidup lebih lama sesuai dengan jumlah sensor yang aktif. Sedangkan pada sistem kemacetan total akan menghidupkan seluruh lampu merah pada semua jalur. Tabel 3 menunjukan waktu yang diprogam untuk setiap sistem 
Tabel 3. Rancangan waktu pengaturan traffic light

\begin{tabular}{|c|c|c|c|c|c|}
\hline \multirow{2}{*}{ Lampu } & \multicolumn{5}{|c|}{ Waktu yang dialokasikan } \\
\cline { 2 - 6 } & \multirow{2}{*}{ Normal } & \multicolumn{3}{|c|}{ Sistem Kepadatan } & $\begin{array}{c}\text { Kemacetan } \\
\text { Total }\end{array}$ \\
\cline { 3 - 6 } & & Sensor 1 & Sensor 2 & Sensor 3 & $\begin{array}{c}\text { Sensor } \\
\text { Kemacetan }\end{array}$ \\
\hline Merah & 2 Detik & - & - & - & $\begin{array}{c}\text { Tidak } \\
\text { terbatas }\end{array}$ \\
\hline Kuning & 3 Detik & - & - & - & - \\
\hline Hijau & 10 Detik & 15 Detik & 20 Detik & 25 Detik & - \\
\hline
\end{tabular}

Pada sisten normal, lampu merah akan menyala selama 2 detik, lampu hijau selama 10 detik dan lampu kuning selama 3 detik. Setelahnya sistem akan mematikan lampu merah dan menghidupkan lampu hijau pada jalur berikutnya.

Tabel 3 juga memperlihatkan bahwa pada sistem kepadatan, lampu hijau menyala lebih lama. Jika hanya sensor 1 yang aktif, maka waktu penyalaan lampu hijau bertambah selama 5 detik. Jika sensor 1 dan sensor 2 yang aktif, waktu tambahan adalah 10 detik dan jika semua sensor pada suatu jalur aktif akan membuat lampu hijau menyala lebih lama lagi (15 detik).

Sistem kepadatan bergantung pada jumlah sensor yang aktif. Berikut adalah kriteria pengaktifan suatu sensor.

1. Sensor 1 akan aktif bila terhalang kendaraan secara berterusan selama 5 detik atau lebih.

2. Sensor 2 akan aktif jika kendaraan telah menghalangi sensor selama 5 detik berterusan dan sensor 1 masih aktif.

3. Sensor 3 akan aktif jika kendaraan telah menghalangi sensor selama dari 5 detik berterusan dan sensor 1 serta sensor 2 masih aktif.

Jika Sensor kemacetan total aktif, akan menghidupkan semua lampu merah. Sensor ini akan bekerja apabila ada kendaraan berhenti pada pertengahan persimpangan sehingga menghalangi kedua sensor yang dipasang pada pertengahan simpang selama 1 menit berterusan. Sensor tersebut akan non aktif kembali jika tidak lagi terhalang secara berterusan selama 30 detik.

\section{HASIL DAN PEMBAHASAN}

Penelitian ini di lakukan melalui tiga tahapan pengujian yaitu: sistem normal, sensor pada setiap jalur dan pengujian sensor kemacetan total.

\section{A. Pengujian Sistem Normal}

Pada tahapan ini akan dilakukan pengujian dengan menggunakan LED merah, kuning dan hijau yang akan di hubungkan pada panel output PLC. Hal ini dilakukan untuk melihat apakah sistem yang telah di program sebagai sistem normal berjalan sesuai dengan yang diinginkan. Gambar 5 memperlihatkan nyala lampu-lampu LED saat sistem normal sedang aktif. Pada gambar tersebut terlihat lampu LED yang hidup pada salah satu jalur adalah kuning, sementara jalur lain merah.

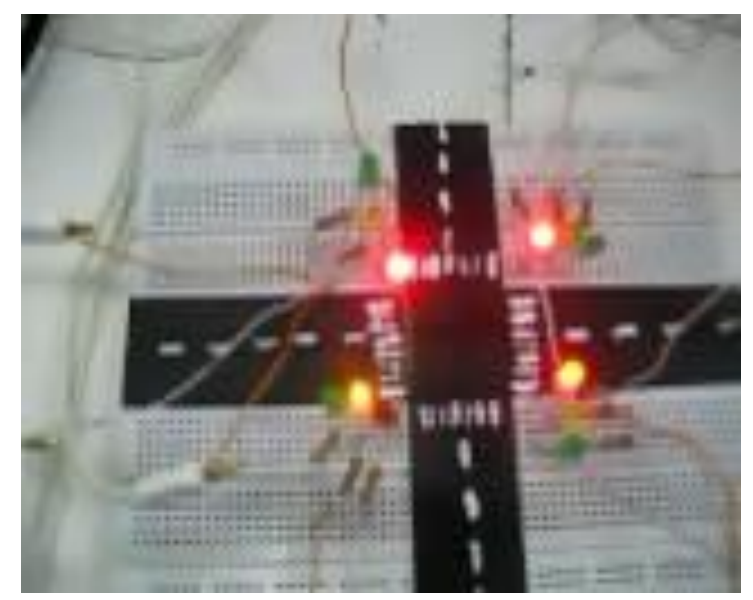

Gambar 5. Tampilan saat sistem normal

\section{B. Pengujian Sistem Kepadatan}

Gambar 6 memperlihatkan tampilan fisik dari rangkaian sensor. Sementara Gambar 7 memperlihatkan keadaan saat salah satu sensor di suatu jalur aktif. Lampu hijau pada jalur tersebut menyala lebih lama dibandingkan pada saat ketika sistem normal aktif.

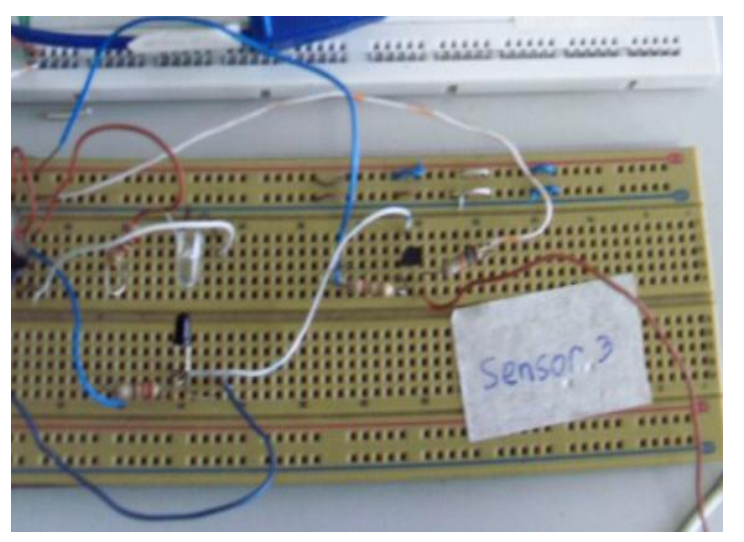

Gambar 6. Tampilan rangkaian sensor infrared 


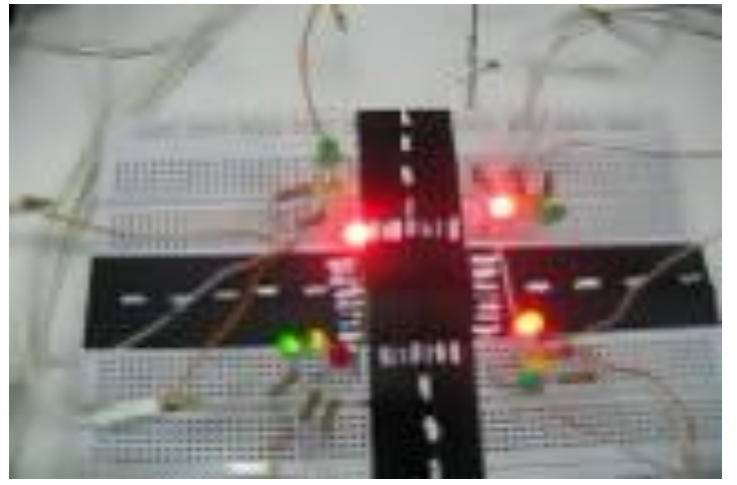

Gambar 7. Tampilan saat sistem kepadatan

\section{Pengujian Sistem Kemacetan Total}

Pada tahap ini akan dilakukan pengujian rangkaian sensor untuk kemacetan total. Sensor ini akan bekerja bila terjadi kemacetan yang lama pada pertengahan simpang sehingga menyebabkan aktifnya kedua sensor kemacetan total. Gambar 8 menampilkan kondisi ketika sistem tersebut aktif, semua lampu merah menyala bersamaan.

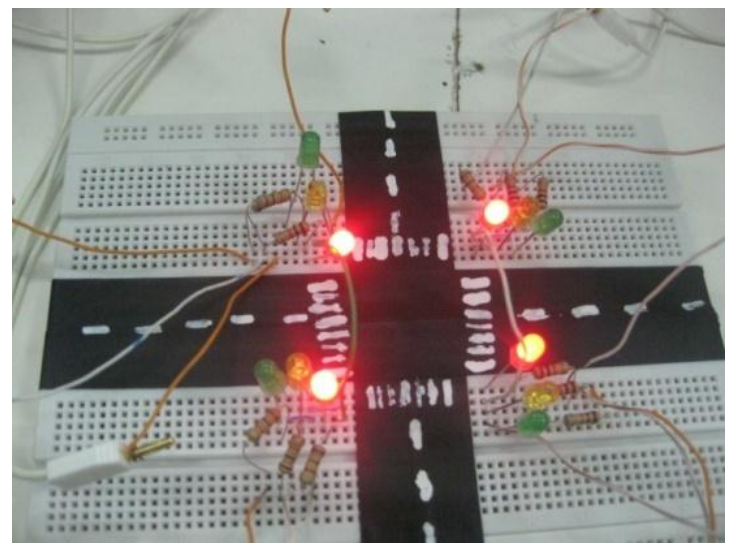

Gambar 8. Tampilan saat sistem kemacetan total

\section{Perhitungan Waktu Tunggu Sistem Normal}

Jika sistem sedang beroperasi secara normal, maka lamanya waktu tunggu dari sebuah kendaraan yang mengantri adalah sebagai berikut:

$$
3 \times \mathrm{T}_{\text {hijau }}+3 \times \mathrm{T}_{\text {kuning }}+4 \times \mathrm{T}_{\text {merah bersamaan }}
$$$$
3 \times 10 \text { detik }+3 \times 3 \text { detik }+4 \times 2 \text { detik }=47
$$
detik

Dari perhitungan diatas dapat terlihat lamanya waktu kendaraan menunggu giliran lampu hijau adalah selama 47 detik pada saat sistem normal bekerja.

\section{E. Perkiraan Waktu Tunggu Sistem Kepadatan}

Pada mode kepadatan, ketika sebuah sensor pada suatu jalur atau lebih aktif, maka waktu tunggu kendaraan akan bertambah lama. Waktu tambahan yang diberikan jika hanya sebuah sensoryang aktif adalah 5 detik.

Jika hanya sebuah sensor yang aktif (dalam hal ini sensor 1 pada jalur mana saja), maka waktu tunggu akan bertambah selama lima detik menjadi 52 detik. Waktu tungga paling lama dicapai ketika kondisi semua sensor pada jalur selain jalur pengantri aktif. Ini akan memberikan tambahan waktu selama 9 x 5 detik $=45$ detik, atau total waktu tunggu adalah 47 detik +45 detik $=92$ detik.

Waktu tunggu dari suatu kendaraan akan berbeda tergantung kepada jalur pengantri dan jumlah sensor yang aktif pada jalur-jalur selain jalur pengantri. Berikut adalah contoh estimasi perhitungan lamanya waktu tunggu.

Kondisi jalur 1, sensor 1 aktif

Kondisi jalur 2, sensor 1 dan sensor 2 aktif

Kondisi jalur 3, tidak ada sensor yang aktif

Kondisi jalur 4, sensor 1, sensor 2 dan sensor 3 aktif

\section{Waktu tunggu kendaraan:}

Pada jalur $1=47$ detik $+5 \times 5$ detik $=72$ detik

Pada jalur $2=47$ detik $+4 x 5$ detik $=67$ detik

Pada jalur $3=47$ detik $+6 x 5$ detik $=77$ detik

Pada jalur $4=47$ detik $+3 \times 5$ detik $=62$ detik

\section{F. Waktu Tunggu Sistem Kemacetan Total}

Ketika sistem ini bekerja, semua lampu merah akan menyala. Artinya semua kendaraan yang mengantri tidak diperbolehkan melewati persimpangan. Kendaraan baru boleh melewati persimpangan ketika sistem ini non aktif (kembali ke sistem normal atau sistem kepadatan).

Lamanya waktu tunggu kendaraan ketika sistem kemacetan total aktif tidak ditentukan. Hal tersebut tergantung kepada kondisi kemacetan di persimpangan. Jika oleh suatu hal (misal terjadi trabrakan kendaraan) kemacetan baru teratasi setelah satu jam, maka selama itu pula kendaraan harus menunggu.

Dalam desain ini tidak menggunakan jenisjenis lampu yang sesungguhnya digunakan pada traffic light yang telah dipakai. Lampu yang digunakan adalah LED, hal ini untuk 
memudahkan pengujian hardware. Selain itu, penggunaan lampu sesungguhnya tidak akan mengubah desain program yang telah dirancang.

\section{KESIMPULAN}

Adapun kesimpulan yang didapatkan pada penelitian ini adalah:

1. Sistem kontrol traffic light adaptif dirancang bekerja berdasarkan sensor-sensor yang terpasang pada jalur-jalur dan persimpangan.

2. Sistem dirancang untuk beroperasi pada tiga kondisi, yaitu: sistem normal, sistem kepadatan dan sistem kemacetan total.

3. Waktu tunggu minimal kendaraan pada suatu jalur adalah 47 detik dan waktu tunggu maksimum kendaraan pada suatu jalur adalah 92 detik.

\section{DAFTAR PUSTAKA}

[1] Tjia May On, Mardjoko Pono Budi, Martanto Nato, Sistem Pengaturan Lampu Lalu Lintas Secara Sentral dari Jarak Jauh, Jurnal Teknik Elektro, Vol. 9, No. 27, 71-78, Oktober 2007

[2] Handry Khoswanto, Lim Resmana, Ling Budy Lie Sin, Traffic Light Controller Menggunakan Media RF, Jurnal Teknik Elektro, Vol.5, No.1, 25-31, 2005

[3] Afit Al-Farit, Rachmadi, M. Febrian Masum, M. Anwar, Wibowo Adi, Jatmika Wisna, 12 November 2011, Implementasi Prototipe Sistem Pengaturan Lampu Lalu Lintas Terdistribusi Dengan Optimasi Pengenalan Dan Penjejakan Kendaraan Berbasis Pemrosesan Video, KNS \& I11039

[4] Zulfikar, Tarmizi dan Agus Adria, Perancangan Pengontrolan Traffic Light Otomatis, Jurnal Rekayasa Elektrika Vol. 9, No. 3, April 2011

[5] Andalia, Susiana, Perancangan Prototif Traffic Light Berbasis Mikrokontroler AT89S52, Fakultas Matematika dan Ilmu Pengetahuan Alam Universitas Sumatra Utara, Medan, 2005

[6] Kurniawan, Iwan Y. S., 2012, Prototype Traffic Light Adaptif untuk Pertigaan Ruas Jalan Berbasis Programmable Logic Controller (PLC) Omron, Jurusan Teknik
Elektronika, Fakultas Teknik Universitas Negeri Yogyakarta, 2012

[7] Wicaksono, Handy, Programmble Logic Controller: Teori, Pemograman dan Aplikasi Otomatis Sistem, Graha Ilmu, Yogyakarta, 2009

[8] SIEMENS Company, 2007. SIMENS Simatic S7-300 Getting Started for Fisrt Time Users. s.1.:SIEMENS.

\section{Biodata Penulis}

Zulfikar, memperoleh gelar S.T. dari Universitas Sumatera Utara pada tahun 1999. Gelar M.Sc diperoleh dari King Saud University pada tahun 2011. Sekarang menjadi staf pengajar di Jurusan Teknik Elektro, Fakultas Teknik, Universitas Syiah Kuala. Saat ini aktif melakukan riset dibidang Perancangan VLSI dan System on Chips.

Tarmizi, memperoleh gelar S.T. dari Universitas Sumatera Utara pada tahun 1998. Gelar M.Sc diperoleh dari Universiti Sains Malaysia pada tahun 2008. Sekarang menjadi staf pengajar di Jurusan Teknik Elektro, Fakultas Teknik, Universitas Syiah Kuala. Saat ini aktif melakukan penelitian di bidang renewable energy.

Oktavina, memperoleh gelar S.T. dari universitas Syiah Kuala pada tahun 2014. Saat ini aktif melakukan riset tentang penggunaan PLC. 